\title{
1. Trial and error: Policy experiments, failures and innovations in Central and Eastern Europe
}

\author{
Agnes Batory, Andrew Cartwright and \\ Diane Stone
}

\subsection{INTRODUCTION}

In the early part of the last decade, a new European Union funding programme was introduced for rural areas in Central and Eastern Europe (CEE). Originating in 1980s France, the LEADER programme was widely seen by the EU as a central policy tool for bottom-up innovation and growth, especially in areas struggling to adapt to out-migration and the decline of agricultural employment. Project funding was available for implementing local territorial development plans, which would be overseen by 'Local Action Groups' (LAGs) made up of representatives from businesses, civic groups and local authorities (Macken-Walsh 2009). The policy goals were ambitious: sustainable development, mitigating climate change, countering social exclusion and promoting economic revival in the countryside. Yet there was a problem which both confused and frustrated the implementing agencies: the actual amount of project funding available was relatively modest, particularly in the light of the scale of rural problems in the regions. Rather than helping maintain strained public services and creating widespread opportunities that could halt out-migration, the LAGs sponsored projects that appeared more modest and marginal, even eccentric, such as reviving local dance festivals, erecting public notice boards, establishing wildlife trails and publishing local recipe books.

Despite the slightly bombastic rhetoric of the programme, in a number of areas of Central and Eastern Europe LAGs came to be understood locally as a kind of folk preservation society, familiar from socialist times, which would help preserve local cultural traditions but would be almost wholly irrelevant to more pressing questions of rural development. Thus LAGs were reinterpreted as something similar to old socialist era institutions that ran so-called 'cultural houses' - state sponsored village halls 
for official and social events which functioned as meeting places for choir practice, Friday night discotheques for the young, and drawing lessons for children. Such an outcome was in stark contrast with the original plan, and may have come as somewhat of a disappointment to EU officials who saw LAGs in the vanguard of social innovation and rural revival. In their reinterpreted form, LAGs were certainly meaningful and useful, but not in the sense that was intended.

Such processes of recognition and reinterpretation characterized many projects and programmes, and sometimes entire policy fields, in the EU's 'new' member states. For instance, as András Tétényi shows in Chapter 8 of this volume, the idea that the CEE countries should be providing development assistance for poorer countries came as somewhat of a surprise to both the European Commission, which assumed such a policy was already in place, and the individual candidate countries themselves, which were more used to their status as aid recipient rather than donor (Szent-Iványi and Tétényi 2008). Despite the lack of relevant institutions, expertise and legislation, the accession countries were expected to sign up to offering 0.7 per cent of their GDP, for instance, committing themselves to fulfilment of the United Nation's (UN) Millennium Development Goals, and administering aid in line with the latest best practices with their concern with equal partnerships, efficiencies and coordination. In this regard, the CEE countries received training and support from a bewildering array of actors, not least Canada, Japan, Finland, Sweden and the UK, as well as international agencies such as the United Nations Development Programme, the World Bank and of course the European Commission. In the eventual implementation of official development assistance (ODA) policies, significant differences appeared among the CEE countries in terms of the size of budgets, scope of work and political profile. In some cases, countries assumed significant responsibilities, and were quick to align themselves with the goals and mores of the international development community. In other cases, however, CEE countries reinterpreted the goals of official development policy in ways that profoundly puzzled their original advisors. For example, the largest recipients of Hungarian government bilateral ODA have not been the least developed countries in Africa and Asia, but the minority Hungarian community in neighbouring Ukraine and Serbia - thereby turning ODA into a policy tool for maintaining close links with co-ethnics divided by borders in Europe.

These examples illustrate some of the conundrums addressed in this edited volume on Central and Eastern European countries as they adopted and translated foreign ideas and policies in the path towards European Union accession and beyond. They show how policies with strong external origins go through complex processes of interpretation and 
implementation that can lead to outcomes that significantly diverge from the original intention, albeit retaining certain formal commonalities to the original.

The book is structured around two central themes. We address, on the one hand, the concepts of policy transfer and policy diffusion and, on the other, the concept of policy failure and success within the general context of Europeanization. The authors in the volume show many different features between those two poles, covering a range of phenomena and according a variety of labels. Around the policy success pole are terms such as 'convergence', 'compliance', 'adoption' and so forth. Around the pole of failure come terms such as 'back-sliding', 'policy reversal', 'resistance' and 'lack of political will'. The seemingly straightforward aim of assessing the success or failure of policy transfer is complicated by a wish to provide a more complex understanding of both the interpretative processes and the dynamics of translation. The central questions guiding this volume were the following:

- What is the origin of the policy/institution/idea transferred or diffused to CEE countries?

- To what degree was the policy/institution/idea transferred intact? Was it a faithful copy or was it emulated with a view to improving on the original? Was it used merely as an inspiration? Did it result in a synthesis or was it a hybrid, as Dolowitz and Marsh (1996: 351) might have labelled it?

- Did the resulting policy or institution come to be viewed as a success or failure, or somewhere in between? Could the process of adoption/ adaptation be a success, but seen as a failure when it came to implementation and application?

As these questions imply, while the contributors in this volume are interested in the sources of policy ideas, this is balanced with an analytical concern to address what happened to those ideas and policies in the processes of transmission and transplantation and eventual application on the ground.

The focus on CEE requires little explanation. The process of social, economic and political change provides fertile soil for empirical inquiries on the transfer, diffusion and fate of external models. In the 1990s and early 2000s, the EU, but also almost every other major international organization, was present with policy advice, technical assistance, conditionalities and ideas. International civic groups, from global NGOs to private philanthropy, promoted a wide range of 'goods', from election campaign techniques to know-how in enforcing freedom of information legislation, 
helping civic group start-ups or working for minority protection. The original moments of transfer attracted considerable scholarly attention, and yet it is our contention that after over a decade of EU membership we need to revisit these processes and analyse whether the 'implants' have taken root, grown and perhaps borne fruit, or whether they have morphed into something quite distinct from what was originally intended and envisaged.

The chapter is structured into a further four sections. Section 1.2 covers some of our key concepts regarding policy diffusion, transfer and translation as well as the various understandings of policy failure and success. Section 1.3 focuses on the specific context of Central and Eastern Europe and the experiences of accession countries. Section 1.4 provides an overview of the subsequent chapters. Finally, in section 1.5 we briefly offer some thoughts as to the main findings we can draw from the chapters in the volume (a task that Chapter 10, the concluding chapter, by B. Guy Peters will undertake in greater detail).

\subsection{THEORETICAL FOUNDATIONS: POLICY TRANSFER/DIFFUSION AND POLICY SUCCESS/FAILURE}

In this volume, we grapple with several concepts and approaches. First there is the extensive and well established literature on policy diffusion and policy transfer. This is relevant given the explicit transfers of policy that came with the transposition of the acquis communautaire and accession to the European Union. However, to a large degree, this literature has focused on the processes of transmission and initial adoption rather than considerations of longer term compliance and durability. There are also questions regarding the actual effectiveness of such transfers in achieving Europeanization and meeting international standards which relates to the second body of literature which features high in this volume: that of policy failure and policy success. Cross-connecting 'success' and 'failure' are related ideas of policy translation and policy mobilities (from political geography) alongside ideas of interpretation and policy bricolage that emerge within local contexts as part of the processes of 'enrolment' in the foreign but also locally transfigured policies.

\subsubsection{Policy Diffusion and Policy Transfer}

Conceptual development of the ideas of policy diffusion and policy transfer are now well established in the social science literature. This 
sub-section provides a brief overview looking backwards to the political science diffusion literature and cognate policy studies literature on policy transfer, and then forward to the expanding multidisciplinary literature on 'learning', 'mobilities' and 'translation'. The latter is particularly important to overcoming binary distinctions of 'success' and 'failure' to capture the nuances in policy evolution in the region, including various practices of hybridization, experimentation and bricolage with the international best practices, standards and policy prescriptions coming from outside the new member states, and in drawing attention to methodological and epistemological issues of interpretation.

Policy diffusion is 'the process by which an innovation is communicated through certain channels over time among members of a social system' (Berry and Berry 1999: 171). These patterns of sequential adoption of an innovation emerge incrementally. They can be propelled by: a policy community of like-minded policy thinkers and practitioners; the geographic or cultural proximity of policy arenas; the leadership effect of 'pioneer states' that prompt emulation among 'follower states' (although in this respect there can also be followers who turn into 'laggards'); or, finally, authoritative inducement from a stronger state, international organization or other persuasive actor. The 'power of global models' - liberalism or democracy - is increasingly taken for granted (Dobbin et al. 2007: 450). However, the focus on the patterns whereby 'models' spread at the macrolevel to the widespread adoption of specific policy tools at the micro-level has led some to complain that there is not enough attention to how policies or practices are altered during processes of adoption. By observing and mapping policy adoption, both the political actors involved and the content of what is being spread are of less interest when the original policy is presumed to be contagious. In this regard, the outcomes of policy convergence are viewed as driven by structural forces and path dependencies.

By contrast, policy transfer studies have emphasized the role of agency and the decision-making dynamics that are internal to political systems. The logic of selecting policy ideas - whether this is by 'systematically pinching' (Schneider and Ingram 1988) or a voluntary process of 'lessondrawing' (Rose 1993) by civil servants and politicians seeking to interpret 'best practice' by imitation and modification - was central to many analyses. In this field, greater attention is accorded to what is transferred, specifically policies, institutions, ideologies or negative lessons (see Stone 2012). The different degrees of transfer are also a common theme, from straightforward copying to investigating the power dynamics of persuasion, indirect pressure and apparent coercion whereby policy transfers may be achieved through imposition.

Clearly there are significant similarities between transfer and diffusion, 
and despite the different terminology each points to circumstances of 'policy interdependence' (Gilardi 2012). Emerging out of different scholarly tributaries, the terms are sometimes interchangeable, with both streams attracting similar criticisms. In the past decade, various studies of transfer or diffusion have challenged this assumption of undiluted dichotomous diffusion or unmediated 'import' of transferred ideas (inter alia, Lendvai and Stubbs 2007; Sissenich 2008; Tews 2009). Rather than have a linear process of transmission, it is possible to learn from more than one jurisdiction at a time, and to take away a multiplicity of lessons. This can result in selective borrowing leading to policy hybrids and adaptive innovation that can make policy development fit local conditions.

A further interpretative dynamic occurs when moving away from the official domain of policy-making where politicians and civil servants are the main channels and conduits for addressing the wider universe of policy translators. A good deal of the diffusion and transfer literature has focused on exchanges amongst government elites. A smaller but growing body addresses the role of international organizations and transnational policy communities in the spread of policy, and the role of non-state actors in broadcasting policy approaches. The latter group - a mixed cadre of NGOs, foundations, think tanks, consultancy firms and so on - have been associated with 'soft' forms of transfer, such as the spread of norms, logics and justifications via professional communities or networks, as a complement to the 'hard' or legal transfer of policy tools, structures and practices.

Similarly, the rationalist underpinnings of agent directed transfer has been criticized for neglecting the complexity of context (inter alia, Dwyer and Ellison 2009; Newburn 2010) and the need for interpretation or experimentalism (Sabel and Zeitlin 2012) in the assemblage of policy in local political ecologies (Prince 2009). While national decision-making can be influenced by diffusion, policy innovations elsewhere are not in themselves sufficient condition for another jurisdiction to adopt the same policy. Internal factors such as the power dynamics of political interests and a polity's socio-historical make-up can be far more persuasive than external factors. Accordingly, the concept of 'policy translation' has gained traction as an alternative perspective that places less emphasis on origins and dissemination, preferring to stress the importance of local sources of inspiration, learning among importing policy communities, and the more unpredictable processes of trial and error.

\subsubsection{Translating Policy Successes and Failures}

Policy failure has re-emerged as a field of analysis in comparative politics and policy studies. In its most simple rendition, 'Failure is the mirror image 
of success: A policy fails if it does not achieve the goals that proponents set out to achieve and opposition is great and/or support is virtually nonexistent' (McConnell 2010: 356). However, as McConnell argues, not only do policy outcomes have 'multiple dimensions', but the politics of policy are more complicated: proponents are more likely to emphasize achievements, while opponents stress the limitations and flawed execution. There is also a tendency to lump together the linked but nonetheless distinct ideas of state failure, governance failure and policy failure (Peters 2015).

State failure is an extreme condition when governments have lost the capacity to deliver basic public services and public order due to war and unrest, and/or usurpation by warlords, clans or others. This is not the focus of this volume. Rather, we look at governance failure, which is 'less dramatic than state failure, albeit still significant involving the incapacity to provide systematic direction to the society and economy' (Peters 2015: 263). Governance failures arise from the inability to generate workable compromises because of ideology and politics, or through lack of cooperation and coordination between government departments and bureaucratic agencies because of the cross-sector nature of policy concerns, for example. However, the remedy for these types of failures extends well beyond the design of public policies into the realm of society and political economy.

Policy failure can occur independently from the above types. Even with governance failure, it is feasible to deliver effective policies in a range of policy arenas. While policy failures are seemingly common, and represent perverse public value, nonetheless this type of failure is 'not linked to the organic structure of the state'; instead a policy is 'an instrument that can be manipulated in order to produce better results' (Peters 2015: 264). The distinctions are important for the discussions in this volume. Awareness of these distinctions sharpens understanding of the causes of the limited successes of candidate countries in reaching policy outcomes. As Peters puts it, is the problem 'more a function of the designs of those policies and the politics involved in their implementation, or are these failures more a function of general failures within the governance systems within which policymaking is embedded, or the interactions between these possible causes?' (Peters 2015: 264). In other words, 'any specific policy failure may be only a symptom of a broader failure in governing'. Addressing an instance of policy failures per se may result in an analysis 'only on the proximate "causes" of observed failure rather than on more deeply seated roots of failure' (Peters 2015: 264).

By making the link to policy failure, the study of policy diffusion and transfer becomes 'the object of debate rather than facilitating analyses of the social processes that constitute policy transfer' (McCann and Ward 2012: 327). Treating policy transfer as the dependent variable entails 
seeking to understand processes of Europeanization or donor conditionality. Alternatively, if this phenomenon is treated as the independent variable, then the analytical focus becomes one of addressing the relationship between policy transfer/diffusion and subsequent policy outcomes (Marsh and Evans 2012: 589).

One set of dynamics contributing to policy failure concerns uninformed, incomplete or inappropriate transfers (Dolowitz and Marsh 2000: 17). Uninformed transfer happens when policies are transferred with insufficient knowledge about how and why they 'work' in their original setting. Incomplete transfer results when some features of a policy are transferred, but others are not, where success in the original jurisdiction depended at least in part on those features that were not transferred. The two chapters that address pension policy exemplify aspects of incomplete transfer. Finally, inappropriate transfer occurs when the contextual factors - cultural, political, economic - are so different, which leads to differences in policy outcomes in the countries concerned. This final type of failure has been well documented by Peter Larmour in Foreign Flowers (2005), which charts the failure of many Commonwealth institutional transfers to the Pacific island states since the British colonial era.

A second set of dynamics resides with importing jurisdictions and the concept of 'negative lesson-drawing'. 'Back-sliding' may represent a belated and ex post facto form of negative lesson-drawing. As the EU accession was largely characterized by an asymmetric interdependence for 'subordinate' Central and Eastern European country (CEEC) recipients, the subsequent post-accession tactics of policy resistance may account for the phenomenon of 'back-sliding' (Bache and Taylor 2003; also MeyerSahling 2011). Working with such loaded terminology helps in querying assumptions of undiluted diffusion or unmediated 'import' of transferred ideas emanating from the EU in a one-way process and remaining preserved in their original form (inter alia, Lendvai and Stubbs 2007, 2009; Sissenich 2008; Tews 2009).

In addition, there can be 'dysfunctional' transfer, that is, dysfunctions resulting from 'normative mimicry, or market pressures, whereby overcommitted policymakers have responded to complexity and crisis by unreflectively cutting and pasting from foreign models' (Sharman 2010: 623; also Moynihan 2006). This is a form of 'satisficing' whereby the adoption of international best practice represents a 'symbolic act through which politicians seek to enhance their status, credibility or "modernity". Compared to the idea of policy learning, or even "bounded learning", this mimicry or emulation is "blind" as "it does not entail enhanced reflection"" (Meseguer 2005: 79). Emulation is ad hoc and piece-meal, reflective of the transfer of rhetoric and ideology. 
Then there are deviations from that which was diffused. The "indigenization" of policy occurs over the long term but it might begin at the very point of adoption. Even if there are cases of linear transmission from one jurisdiction to another, the transfer does not create a cryogenically preserved policy for evermore. At some point, the process ends and endogenous forces of mutation take over. Local ownership becomes more pronounced and logics of appropriateness entail a gradual adjustment and modification that lead to outcomes that may not originally have been envisaged.

A third dynamic reinterprets the absence of transfers, distortions or diffusion not as 'failure', 'back-sliding' or incompleteness, but rather as experimentation, learning and 'translation'. This valorizes the reality and extensiveness of hybridity, synthesis, tinkering and adaptation that take place when policies move from one place to the next. It contests the notion that policies are internally coherent, consensually informed 'blueprints'. Instead, unintended consequences and misconstrued policy messages are integral to the assembly and metamorphoses of policy reforms. Policy translation (see, inter alia, Prince 2009; McCann and Ward 2012; Stone 2012) offers a more flexible conceptual framework for comprehending and recognizing value in the learning and policy innovations that come with the trials and errors that are inherent in policy-making. Intended recipients are neither passive nor unchanging ciphers.

The perspective of policy translation also points to a common epistemological conundrum in determining successes or otherwise, namely, the question of who or what is authoritative in making such claims. As Mosse (2005: 34-9) puts it, policy ideas, whether they are expressed in terms of objectives or outcomes, have a certain social work to perform, one that seeks at different stages to enrol, to persuade, to create agreement and to contribute towards wider policy arguments. In this regard, the reconstruction of the process of policy take-up has to consider the sources of information concerning internal hearings, presentations, debates and revisions, but also establish a common understanding as to the significant elements in the development life of the policy. Informants may be privy to inside information on account of their technical expertise, their claims to represent those affected or their position in some implementing agency (Matyas and Zentai 2012). However, their accounts might also need to be qualified to the extent that their actual access to information may be both filtered and limited. The same actor can be both observer and active participant. Empirical reconstructions need to acknowledge how these positions influence their account of the development of the policy. For external commentators, reconstruction poses different questions, requiring alternative techniques bearing in mind what part of the policy cycle is being considered. 
Thus, one recurring theme in this volume is that policy success and failure ought to be seen from more than one perspective. Evaluations by non-governmental organizations (NGOs) or donors of policy reforms may diverge considerably from government reviews. Moreover, there might be shortcomings in reaching particular goals, but these might be overshadowed by additional achievements, even if they were not anticipated beforehand. Yet again, considering success and failure from political, administrative or other perspectives requires some interpretative consensus in order to come to analytical judgements and conclusions.

\subsection{THE CEE CONTEXT: THE EU AS MAIN DRIVER OF 'REFORM'}

The Central and Eastern European region is an eminently suitable region for studying policy transfer and translation processes and their outcomes. The pathways of post-communist transition did not follow a rational process of policy design choosing from a galaxy of potential 'best practices'. Instead, today's realities emerged through a more muddy process of adjustment and learning. The region has long been a location for radical institutional reconstruction: 'awash with imported "solutions", never perfectly replicated, it is a region in which hybrid and "recombined" policy forms have been produced with almost tectonic intensity' (Peck 2011: 780). The process was rarely about policy-makers weighing up the pros and cons of a particular model or practice. Nonetheless the process was 'targeted' in the sense that a lot of reforms were the direct result of the European Commission telling candidate countries how exactly to adopt EU law and practice. This section provides greater detail of the context and trajectories of CEE transition, democratic consolidation and European Union membership.

\subsubsection{The EU as Origin of Policy Transplants}

The countries that joined the EU in 2004 are still referred to as 'the new member states', despite the fact that over a decade has elapsed (Romania and Bulgaria joined later, in 2007). The term has some analytical value since it draws attention to the centrality of EU membership, first as a goal that oriented transformations away from central planning and one-party systems to capitalism and democracy, and second as a source of very concrete legal obligations stemming from membership. This alone makes the CEE countries interesting cases for studying policy diffusion/transfer and the way that external models take hold, or fail to take hold, and/or are adapted and shaped by contextual factors. 
Highlighting the generic among CEE countries, the term 'new member states' obfuscates the differences that existed, and continue to exist, within the region. Communism was not 'all the same' across the Eastern bloc, ranging from severe repression in Romania, Poland and Bulgaria to Hungary's relatively lax goulash-communism, leaving behind distinct resources and liabilities for the post-communist elite. Countries differed in their ability to bring into office reform-minded new political elites, which then pursued various modernization agendas, with a resulting variance in political economy across the region (Bohle and Greskovits 2012). This variation fractured external influence, with the result that the present CEE landscape is a patchwork rather than a picture of uniformity or convergence.

The phrase 'new member states' also de-emphasizes the importance of the period since accession, as if, with membership finally secured, the CEE countries somehow reached a finalité. Whereas the pre-accession years are seen as a period of dynamic, linear progress towards 'graduation' and full membership, the post-accession years are characterized as simply continuing along this trajectory, albeit without the earlier guiding external influence. A wave of influential books was published around the time of enlargement (2004), taking stock of changes thus far and offering predictions about how these countries would fare once inside the Union (Cowles et al. 2001; Dimitrova 2004; Schimmelfennig and Sedelmeier 2005; Vachudova 2005; Grabbe 2006). Yet the past decade offers the conceptually most fruitful period for observing how the CEE countries have come to adapt, translate, localize and generally make their own (or fail to make their own) the policies, institutions and ideas that have been brought by the EU, sometimes 'progressing', sometimes reversing or side-stepping earlier achievements or implants.

The academic literatures most relevant to dissecting the EU's influence on the CEE countries are those dealing with Europeanization, conditionality and, particularly since accession, compliance with EU norms. 'Europeanization' as a term has often been criticized for lacking conceptual clarity (Flockhart 2010), but it is so widely accepted in the literature as to be almost inescapable. It is normally taken to mean 'different forms of diffusion processes of European ideas and practices across time and space' (Flockhart 2010: 788) or simply the EU's impact on whatever is the object of study: member states (polity), party systems, policies or normative frameworks (Sedelmeier 2011). Europeanization is also seen as "the "downloading" of EU policy into the national polity' (Grabbe 2006: 4). Common to these definitions is the idea of the EU as the origin of models, templates and obligations, and of the CEE countries (and other member states) as addressees, recipients and (willing) takers. Embedded in such definitions is 
a perception of structural and linear processes of policy diffusion/transfer rather than a reciprocal agent-driven negotiation of policy translation. Europeanization in the latter sense is seen as the reverse of 'uploading' processes, whereby the member states shape EU policies and institutions.

The first noteworthy feature of the Europeanization of the CEE countries is the sheer scale of the process: that is, the extraordinary scope of institutions, processes and ideas that have been diffused/transferred, primarily in the years prior to accession, and the generally high degree of influence these have had. This has been observed, on the one hand, in relation to the very nature of the CEE countries' political regimes. In the early 1990 s, as these countries emerged from four decades of communism, the aspiration to 'return to Europe' symbolized a desired end-goal for macrolevel transformations. The wish to join the club of Western European countries was a strong pull factor and enjoyed widespread support among political elites in CEE countries - partly because in the early 1990s, in marked contrast with today's post-Brexit context, European integration enjoyed a period of dynamic expansion. At this stage, primarily diffusion processes were at play, with CEE political elites driven by a desire to emulate the socio-political arrangements of the more successful Western half of the continent.

Soon, however, the EU insisted that respect for liberal democratic principles was a formal requirement for aspiring members. From 1992, progress in democratic reforms was a condition for receiving financial assistance under what was originally Poland and Hungary: Assistance for Restructuring their Economies (PHARE) (the EU's aid programme of 'Assistance for Economic Restructuring' for the CEE countries, which widened from Poland and Hungary; Schimmelfennig et al. 2005: 30), and the 1993 Copenhagen European Council famously adopted 'the stability of institutions guaranteeing democracy, the rule of law, human rights and respect for and protection of minorities', the so-called Copenhagen criteria, as precondition for eventual membership. To what extent the EU has been successful in 'anchoring democracy' in the CEE countries is a matter of debate, but the ambition of the Union to effect wholesale political transformations by conscious, strategic transfer of normative requirements is beyond doubt.

The scale of Europeanization is also significant with respect to policy: the penetration of EU law, 'good practices' and procedures is observable in areas ranging from veterinary standards to public administration and the territorial organization of the state, albeit to various degrees. For the first time, prospective members were required to adopt the whole of the acquis communautaire prior to accession (this was not a condition in earlier rounds of enlargement). With the beginning of accession negotiations 
in 1998, these requirements were communicated, in great detail, in the Commission's annual monitoring reports, which essentially functioned as legislative agenda for candidate governments. For several years, the incorporation of the acquis into domestic legal norms dominated parliaments. The volume of legislation was at times enormous - to the extent that parliaments kept up with the timetable of accession negotiations by establishing fast-track, low scrutiny procedures (Schimmelfennig and Sedelmeier 2005: 2). As Jacoby points out, the flood of an estimated 10000 directives or 80000 pages of EU legislation to transpose resulted in a 'cookie-cutter method of transfer' in national ministries (1999: 65).

At this stage, the process resembled ideal-typical 'linear' policy transfer, and especially in highly technical areas the CEE countries adopted EU rules with little thought to implementation. '[A] lack of adaptation to specific circumstances in each country as well as an absence of broad consultation of affected groups during the preparation of the laws' was characteristic of pre-accession legal alignment (Falkner and Treib 2008: 298-9). As Dimitrova (2004: 8) argues, '[e]nlargement is explicitly defined by the Commission and accepted by the candidates as an "asymmetrical process" of taking over the rules of a club ... [and consequently] political elites in CEE have limited control over the institutional changes they have undertaken to affect'. The impact this has had on the CEE countries is difficult to overestimate: EU policy influence has generally been described as strong and direct across most policy areas regulated by the acquis (Sedelmeier 2011: 22).

As to the mechanisms through which the EU has 'driven [the CEEs] to change', as Dimitrova (2004) put it, the key role was played by conditionality. Considerable scholarly attention has been devoted to when and under what conditions conditionality 'worked best', in the sense of eliciting the highest levels of compliance. Such accounts tend to be rooted in rationalist institutionalism, and rely on incentive structures for an explanation (see Sedelmeier 2011). Consequently, conditionality is seen as productive largely because the ultimate reward of membership was strongly desired by the CEE countries, thus offering the EU strong leverage backed up by the possibility of denying or delaying accession. Clear requirements, a credible membership perspective and strong monitoring capacities combined to put the Commission in an extremely strong position vis-à-vis the negotiating governments. This strengthened the foundations of policy transfer, in these accounts conditioned by domestic adaptation costs, operationalized as veto players inside the CEE countries (Schimmelfennig et al. 2005).

Although the CEE countries were of course always free 'to walk away', the power asymmetry was so pronounced as to give the Commission licence to ask for more from the accession countries than from existing 
member states. Not only did the Commission have competencies towards the CEE countries that member states had not accepted for themselves (Grabbe 2006: 36), but at times conditionality covered areas not included in the acquis, or obligations member states had not complied with. A prominent example is anti-corruption, an area not covered by the acquis yet prominently and consistently included in pre-accession conditionality (Batory 2010). Moreover, leverage gained through membership conditionality was used to reinforce standards set by other international organizations, notably the World Bank and the Council of Europe (CoE), with, for instance, candidate countries explicitly recommended to adopt various CoE conventions. 'Parallel and additive conditionality' was the case particularly in human and minority rights, where $\mathrm{CoE}$ and Organization for Security and Co-operation in Europe (OSCE) demands worked in tandem with the Copenhagen criteria (Schimmelfennig et al. 2005: 33).

At times, the accession countries voluntarily assumed more than that which was strictly required of them, going beyond conditionality. Instrumental rational motivations do not fully explain these cases in particular, or the scale of EU rule adoption in CEE in general. Apart from leverage, 'linkage' is pivotal to the transmission of policies and ideas (Levitsky and Way 2006). The EU is an environment that is dense with policy networks and epistemic communities to which the CEE countries have also been increasingly connected. Through these channels, emphasized in sociological and constructivist institutionalist perspectives, the accession countries 'acquired' policies, institutions and ideas through: elite socialization in EU fora; learning and persuasion; identifying with and accepting the EU as the legitimate source of authority; and the particular resonance of ideas with prevailing norms within the CEE countries (Finnemore and Sikkink 1998; Schimmelfennig and Sedelmeier 2005; Schwellnus 2005). From this perspective, supranational institutions are seen as transfer agents, facilitating and enabling transfer/diffusion rather than 'pushing' EU requirements on behalf of the existing member states, and learning also occurs in horizontal relationships, for instance in terms of lesson-drawing from the experience of one candidate/new member state by another. Rule adoption is seen as a reflective rather than mechanical exercise.

\subsubsection{Other External Sources of Policy Change}

It should be noted that a number of other organizations were also present in the region, acting as transfer agent and working to enable policy learning. An example is the Organisation for Economic Co-operation and Development (OECD)'s Public Management Programme (PUMA). It has 
several methods for spreading information and provide 'forward thinking' on matters such as national accounting standards, human resources management and 'OECD Best Practices for Budget Transparency' publications, networks of senior officials, conferences and so on $(\mathrm{Pal}$ 2012). Similarly, a joint initiative of the EU and OECD - Support for Improvement in Governance and Management (SIGMA) in Central and Eastern Europe - provided advice on improving public governance at the central government level. Other international organizations and bilateral development agencies - such as the United States Agency for International Development (USAID) and the Swedish International Development Cooperation Agency (SIDA) - sought to provide lessons to boost capacities in public sector administration and policy reforms. With its regional centre in Bratislava, the United Nations Development Programme (UNDP) launched numerous initiatives to support the CEE countries' accession. By and large these initiatives were educational and concerned the promotion of policy learning: that is, 'soft' or persuasive modes of policy transfer. Nevertheless, as our contributors on pension reform (Chapter 3), domestic violence policies (Chapter 4) and Roma initiatives (Chapter 5) discuss, these international actors also mediated Europeanization transfer/diffusion processes and offered distinct interpretations of their own as to what constituted 'best practice'.

Conditionality is the 'hard' dimension of transfer, generally brought about by authoritative and legitimate policy actors such as governments and international organizations. However, the hard transfer of rules, institutions and policy instruments is frequently underpinned by complementary soft processes of training, persuasion and consensus building. The emphasis is on cognition and the redefinition of interests on the basis of new knowledge which affects the fundamental beliefs and ideas behind policy approaches. The mechanisms for such transfer include a wider constellation of individuals, networks and organizations. Think tanks or research institutes, management consultancies, philanthropic foundations, university centres, law firms, scientific associations, professional societies, training institutes and so forth help transfer the intellectual matter that underpins policies. Ordinarily private or quasi-autonomous organizations, many have used their intellectual authority or market expertise to reinforce and legitimate certain forms of policy or normative standards as 'best practice'.

For example, quasi-governmental political foundations such as the German Stiftungen, the British Westminster Foundation for Democracy or, in the USA, the Center for International Private Enterprise were proactive in exporting the principles of market oriented democracies among government officials, businesspeople, media and the public. Independent 
philanthropies have also been important, notably the Open Society Foundations (OSF), in bankrolling exchange programmes or training initiatives for local government officials and national administrators. OSF funded the European Union Monitoring and Advocacy Program of the Open Society Institute (EUMAP) - a programme that monitored the progress of national administrations in the EU accession process on wide-ranging concerns such as minority protection, freedom of information law, and other human rights and rule of law issues. There have been policy parallels in the higher education realm with foundation, bilateral donor support and foreign university partnerships in the flowering of 'Western style' graduate public policy programmes, MBAs and law degrees to prepare new generations of leaders in government, business and the professions (Stone 2007: 547).

\subsubsection{Compliance}

In the decade since the CEE countries gained full membership, the literature dealing with rule adoption in these countries has moved on from Europeanization to the perspective of compliance with EU norms, considering questions such as whether the new member states remain a distinctive group or whether general patterns hold across the EU. In this literature too, compliance is a function of instrumental rationality and/or normative motivations, or a combination of the two. Accordingly, the enforcement approach emphasizes the threat of sanctions, the management approach emphasizes incentives of the 'enabling kind', and the persuasion approach shares normative commitment as a source of rule adoption/transfer processes (for a review see Hartlapp 2007). Commonly used variables, again echoing the Europeanization debate, include 'goodness of fit' as a proxy for adaptation costs, EU enforcement and sanctioning powers, and administrative/government capacity for the former two, and elite socialization, learning effects and particularly 'a culture of compliance' for the latter (for a review see Neyer and Wolf 2005; Falkner and Treib 2008; Angelova et al. 2012; Conant 2012).

As for the findings, scholarship found little evidence for a decrease in formal rule adoption rates following accession, contradicting expectations rooted in incentive-based models of Europeanization. Even in the absence of the leverage afforded to the Commission by membership conditionality, the new member states continued to transpose EU rules. In fact, as Sedelmeier (2008: 806) points out, 'far from constituting an "eastern problem", [in alignment with EU law] virtually all of the new member states outperformed virtually all of the old members during the first four years of membership'. Other studies provide a more varied picture, with 
a number of new member states being highly compliant with EU law after accession whereas a second group was characterized by frequent shortcomings in transposition (Knill and Tosun 2009).

However, studies of this kind tend to rely on data generated from Commission enforcement action, that is, times when the EU's 'guardian of the treaties' takes action to bring errant member states into line. Since this is largely based on formal rule adoption, the data may mask massive policy failures on the ground. Indeed, scholarship that looked into the implementation of laws originating from the EU uncovered major deficiencies: EU directives in social policy remained 'dead letters' in the new member states (Falkner and Treib 2008). Dimitrova's (2010) study found that many of the institutions supporting the functioning of the acquis, also 'imported' from the EU during the accession process, failed to become institutionalized, were reversed in some countries or simply remained 'empty shells'. For instance, the principles of civil service reform, notably the independence of the civil service, promoted by the EU were often reversed following accession (Meyer-Sahling 2006). This body of literature serves to remind us that policy transfer cannot be assumed to be a simple linear process of a model taken, mechanically adopted and implemented, but, as the recent experience of the CEE countries investigated in this volume shows, it is an altogether more complex phenomenon with several theoretically possible outcomes, ranging from success to failure and forms in between.

\subsection{STRUCTURE OF THE BOOK AND CHAPTER CONTRIBUTIONS}

Picking up on the theme of policy failure, Chapter 2 by Achim Kemmerling and Kristin Makszin considers whether too much policy transfer can be a lead cause for policy failure, in this respect via introducing extreme policy volatility. This offers an alternative perspective on the idea of the receptive environment and the importance of policy learning; it also suggests that there is a way around some of the normative problems of judging whether a policy is successful or not. If, as in the case of the privatization of pensions, their focus in the chapter, we see a complete reversal, this can be deemed a failure regardless of whether it was based on sound economic analysis or astute political bargaining; the original reform simply had no chance to mature and bear fruit. The three cases that the authors describe contain significant differences in terms of the stakes involved, the degree of domestic support and the nature of the external protagonists. As noted earlier, in this case (as in others in the volume) the EU was by no means the only instigator of policy reform. Especially in the 1990s, there were a host 
of individual countries and international bodies that promoted different reform directions, for instance the World Bank and the OECD in the case of pension privatization.

In Chapter 3, Dragos Adascalitei and Stefan Domonkos offer a more in-depth discussion of the vagaries of pension reform, but consider the question of policy diffusion from a temporal as well as a spatial dimension. Many former socialist countries saw the introduction of a second, mandatory private pillar as the solution to the question of ageing populations. Why then did the Czech Republic and Romania wait almost ten years after their neighbours introduced the policy? Would there not be evidence of significant peer learning advantage in coming to the party so late, avoiding the mistakes of the early adopters and maximizing the advantages promised by the World Bank? Adascalitei and Domonkos demonstrate that although policy-makers in both countries were in close contact with neighbouring countries, especially Slovak advisors, they were still unable to completely avoid some of the traps of the policy, not least its impact on the existing public pension programme and its ability to attract higher income employees. Interestingly, the late implementation of private pension schemes coincided with a marked cooling of enthusiasm on the part of the main policy protagonists themselves. This might well have led to policy reforms that were less ambitious and, as a result, less able to convince sceptical domestic populations.

In Chapter 6, Gergő Medve-Bálint focuses directly on the EU and cohesion policy as its principal means of supporting economic development and reducing income gaps between more and less wealthy EU members, and within countries themselves. One common experience following the collapse of central planning in CEE countries was a dramatic increase in income inequality within the country, especially between the capital and the rest of the country, but also along other fault lines such as areas of heavy industry and agriculture, areas closer to newer Western markets and areas where there were limited urban populations. Initially, policy-makers in both the Czech Republic and Hungary, Medve-Bálint's country cases, followed their pro-market advisors and resisted calls for strong regional policy. However, largely at the prompting of the EU, both countries later introduced mid-tier intermediate bodies to develop regional policies to help revive backward areas. Implementing the partnership principle - a key requirement in cohesion policy - meant creating new administrative models and charging them with ambitious programmes of policy formation and implementation. The chapter illustrates the unfolding contradiction between policy objectives and techniques in the run-up to accession. Although the EU insisted on regional bodies, in the end it sided with the central governments when they argued that the new entities had 
insufficient capacity to run complex operational programmes. The chapter also highlights policy implementation as an odd mixture of 'success' and 'failure'. On the one hand, CEE countries have secured the majority of cohesion funding; on the other, the democratic potential for decentralized planning and implementation was thwarted by external concerns for optimal resource allocation and accountability.

Not all policy interactions in this volume are at the state/supranational level. There are several examples of other policy actors that can exert influence over the interpretation and application of externally driven policies on sub-state levels. Sara Svensson in Chapter 7 investigates how local authorities understood cross-border cooperation in the framework of Euroregions, a long-standing institutional initiative of the Council of Europe. Euroregions have proliferated in Northern and Western Europe for over 50 years, but appeared in CEE only after 1989. Unlike the regional bodies effectively forced on to the accession countries, Euroregions were voluntary associations aiming to promote peaceful cooperation and mutual aid across national boundaries. With a much more modest budget and limited legal capacity, for CEE countries and Hungary and its neighbours in particular, the motivation to join was driven by, on the one hand, grant opportunities but, on the other, a desire to bolster fraternal ties with ethnic kin who happened to be on the other side of the border. In one respect, this could be seen as circumventing and even contradicting the original idea behind Euroregions: building peace and prosperity through bridging different nations and ethnicities. The question for Svensson is in what sense we can assess the contribution of this institutional transfer. In the end, the process of comprehending or, as the author puts it, reinterpreting the goals of the policy reflects the local priorities of the participants, even when those are antithetical to the pan-European politics of the protagonists.

András Tétényi in Chapter 8 introduces a perhaps unfamiliar policy story, namely the establishment of international development programmes in Hungary. In this instance, there was no single transfer agent, and the process of policy development highlights diverse signs of transfer and diffusion through an eclectic mix of advisors and supporters. At the domestic level, there were none of the high profile stakes that were evident in the privatization and welfare reforms. Development assistance registered very low in public concern and this was reflected in a general lack of interest amongst Parliament and ministries. Tétényi shows how the reluctant Ministry for Foreign Affairs spent years trying to attract law makers' interest and impress on a sceptical public the need to raise levels of ODA spending in line with the Millennium Development Goals. As with other areas of policy development, there was no shortage of advisors and, unlike in cohesion policy, EU member states did have full autonomy as to how 
to pursue their international development objectives. In that regard, policy outcomes did resemble international standards, for example focusing on areas of comparative advantage, working though multilateral programmes and cooperating with domestic civic associations. However, the targets for support clearly reflected Hungary's foreign policy goals and there was an unashamed bias towards ensuring that Hungarian companies benefited from enhanced market access. From this perspective, an initially unfamiliar policy field can be quickly saturated with the concerns and frameworks of related fields, even if, to outside observers, they seem to refute the original policy objective.

Andrea Krizsan in Chapter 4 shows how civil society actors have been influential in the development of new policy fields, in this case the creation of legislation and effective enforcement mechanisms to counter domestic violence in the region. As this was not an EU competence per se, domestic advocates used the panoply of international instruments to argue for legislative reforms, not least a combination of UN-based monitoring mechanisms, as well as the assistance of US-based human rights groups, in the context of EU accession and beyond. The five-country study shows variation in terms of inspiration for policy reform and actual progress in addressing the issue, but also highlights the different ways in which domestic and international civic groups cooperated, sometimes in a topdown, quasi-instructive relationship, in other cases in more horizontal partnerships. As Krizsan puts it, transnational policy actors can mediate between state and non-state actors and, in the absence of local sources of revenue, international foundations can become important means for ensuring civic participation in policy reform, especially when the national context might not be conducive. However, as has become increasingly clear, foreign funding for domestic groups that engage in policy reform is also highly controversial and can lead to damaging allegations of foreign agency and influence peddling.

In Chapter 9, Liviu Matei, Daniela Craciun and Simona Torotcoi make the under-appreciated point that, when it comes to assessing the achievements of the Bologna Process, it is important to be clear what exactly is being assessed. Although CEE countries tended to go for wholesale adoption of higher education reform policies covered by the Bologna Process, sometimes at the expense of national debate and experimentation, it is better to see the various policy transfers as an evolving set of values where eventual assessments are more partial and based on judgement rather than science. By disaggregating the policy process, the authors can point to areas where there are clear and relatively unambiguous achievements, whereas in other areas the score sheet is more open to interpretation and debate. They also show the strong differences in domestic support for these 
European reforms. Even though the European Commission itself has relatively limited formal competencies in higher education policy, it turned out to be probably the most important driver of legislative change in the member states.

In Chapter 5, Viola Zentai provides a theoretically rich and nuanced account of the relative successes and failures of Roma inclusion policy in the region. Considering a period stretching back over 15 years, the chapter shows the different inspirations for national strategic policy frameworks, first within the internationally supported civil society and promoted by the World Bank and then taken up by the European Union. For a host of reasons, the initial promise of transforming agendas and frameworks evaporated in a climate of reluctance and avoidance, despite the very significant support that came from coupling Roma inclusion policy to cohesion fund programmes. Zentai argues that understanding policy experiments and learning in the context of social justice and equality agendas needs to bear in mind the adversarial nature of struggles to change societies. One way in which the topic remains in play is through the, albeit precariously funded, work of networks of shadow reporters, monitors and professionals. Acutely aware of the ways in which national governments can disguise inaction, these national and transnational coalitions remind governments and the EU of their obligations as well as widen the scope for Roma participation in policy formation. However, there remains no guarantee that policy experimentalism will not be used to pursue goals entirely against the original agenda of inclusion.

As bookend to this introductory chapter, Chapter 10, the last chapter, by B. Guy Peters reminds us that, notwithstanding the political appeal of policy transfer for the EU and other international organizations, it is institutional capacity that is the most important element determining whether governments have the ability to adopt and embed policies as anticipated.

\subsection{KEY FINDINGS AND IMPLICATIONS}

There are several themes that connect the contributions to this volume. Beyond illustrating the idea that policy 'transfer' processes are often nonlinear and fuzzy and sometimes counter-intuitive, the chapters highlight the central importance of the views, interests and constellations of the domestic actors that filter and interpret international influences. In this sense, the CEE experience in the years since accession is more about active and sometimes strategic policy imports and policy distortion and less about simple receipt and incorporation of external models. While in the pre-accession years CEE countries were more or less willing and capable 
policy 'takers', in more recent times there are plenty of examples and abundant evidence of the reinterpretation processes central to the policy learning perspective.

A number of chapters also point to the extent to which such local reinterpretations challenge or even contradict the logic behind the original idea or model, either openly or under the surface. Medve-Bálint (Chapter 6), Svensson (Chapter 7) and Tétényi (Chapter 8) give examples of processes whereby the declared policy objective was undermined or hollowed out. For instance, extending the EU's cohesion policy to CEE started out as a decentralization project aimed at decreasing regional disparities, yet these long term objectives were superseded by the short term political exigencies and pragmatism on the side of the Commission in alliance with central state authorities. The idea of Euroregions was promoted as an initiative to foster mutual understanding and economic cooperation in aid of European integration, yet, at least in the Hungarian case, they ended up aiding the 're-unification' of Hungarian-speakers divided by national borders. In a similar light, the introduction of official development policy, rather than serving the goal of redistributing resources from 'rich' European countries to developing countries, was adapted by the Hungarian government as a means of strengthening contacts with countries with Hungarian minorities.

Conversely, other contributions illustrate that CEE countries were at times 'overdoing' policy transfer and learning. This sort of excessive learning seems to have taken place in the case of pension reforms. Kemmerling and Makszin (Chapter 2) and Adascalitei and Domonkos (Chapter 3) indicate that policy-makers in the region can become more zealous defenders of ideas than the original promoters of those ideas themselves. It appears that local champions continued to promote pension privatization even when mounting evidence against the model has shaken confidence in it internationally. As Kemmerling and Makszin furthermore argue, this tendency of taking reforms too far then caused policy-makers to relapse, leaving CEE countries as victims of policy failure due to excessive volatility.

Ultimately, the volume shows that, while the region was awash with foreign models in the transition and accession years, the time since CEE countries have been full EU members often saw these 'implants' change beyond recognition. This may have been because the idea or policy adopted was never fully understood, or because somewhere along the way it became apparent that the objective was better served by other means. Important changes also occurred because policy-makers deliberately redirected a model that was more or less forced on them towards partisan goals. Whatever the case, the resulting landscape in CEE is diverse and unique to the region. As to whether transfer and diffusion processes can 
therefore be considered successful, there is no simple answer. This book merely confirms that policy success or failure is in the eye of the beholder; it is a question of who is asking and where that person is looking.

\section{REFERENCES}

Angelova, M., T. Dannwolf and T. König (2012), 'How robust are compliance findings? A research synthesis', Journal of European Public Policy, 19 (8), 1269-91.

Bache, I. and A. Taylor (2003), 'The politics of policy resistance: Reconstructing higher education in Kosovo', Journal of Public Policy, 23, 279-300.

Batory, A. (2010), 'Post-accession malaise? EU conditionality, domestic politics and anti-corruption policy in Hungary', Global Crime, 11 (2), 164-77.

Berry, F.S. and W.D. Berry (1999), 'Innovation and diffusion models in policy research', in P.A. Sabatier (ed.), Theories of the Policy Process, Boulder, CO: Westview Press, pp. 169-200.

Bohle, D. and B. Greskovits (2012), Capitalist Diversity on Europe's Periphery, Ithaca, NY: Cornell University Press.

Conant, L. (2012), 'Compliance and what EU member states make of it', in M. Cremona (ed.), Compliance and the Enforcement of EU Law, Oxford: Oxford University Press, pp. 1-29.

Cowles, M.G., J. Caporaso and T. Risse (eds) (2001), Transforming Europe: Europeanization and Domestic Change, Ithaca, NY: Cornell University Press.

Dimitrova, A.L. (ed.) (2004), Driven to Change: The European Union's Enlargement Viewed from the East, Manchester: Manchester University Press.

Dimitrova, A.L. (2010), 'The new member states of the EU in the aftermath of enlargement: Do new European rules remain empty shells?', Journal of European Public Policy, 17 (1), 137-48.

Dobbin, F., B. Simmons and G. Garrett (2007), 'The global diffusion of public policies: Social construction, coercion, competition, or learning', Annual Review of Sociology, 33, 449-72.

Dolowitz, D. and D. Marsh (1996), 'Who learns from whom: A review of the policy transfer literature', Political Studies, 44 (2), 343-57.

Dolowitz, D. and D. Marsh (2000), 'Learning from abroad: The role of policy transfer in contemporary policy making', Governance, 13 (1), 5-24.

Dwyer, P. and N. Ellison (2009), 'We nicked stuff from all over the place: Policy transfer or muddling through?', Policy and Politics, 37 (3), 389-407.

Falkner, G. and O. Treib (2008), 'Three worlds of compliance or four? The EU-15 compared to new member states', Journal of Common Market Studies, 46 (2), 293-313.

Finnemore, M. and K. Sikkink (1998), 'International norm dynamics and political change', International Organization, 52 (Autumn), 887-917.

Flockhart, T. (2010), 'Europeanization or EU-ization? The transfer of European norms across time and space', Journal of Common Market Studies, 48 (4), 787-810.

Gilardi, F. (2012), 'Policy interdependence: Transfer, diffusion, convergence', in I. Engeli and C. Rothmayr (eds), Comparative Policy Studies: Conceptual and Methodological Challenges, Basingstoke: Palgrave Macmillan. 
Grabbe, H. (2006), The EU's Transformative Power: Europeanization through Conditionality in Central and Eastern Europe, Basingstoke: Palgrave Macmillan.

Hartlapp, M. (2007), 'On enforcement, management and persuasion: Different logics of implementation policy in the EU and the ILO', Journal of Common Market Studies, 45 (3), 653-74.

Jacoby, W. (1999), 'Priest and penitent: The European Union as a force in the domestic politics of Eastern Europe', East European Constitutional Review, 8 (1-2), 62-7.

Knill, C. and J. Tosun (2009), 'Post-accession transposition of EU law in the new member states: Across-country comparison', in F. Schimmelfennig and F. Trauner (eds), Post-accession compliance in the EU's new member states, European Integration online Papers (EIoP), 13 (Special Issue 2), Art. 18, http:// eiop.or.at/eiop/texte/2009-018a.htm.

Larmour, P. (2005), Foreign Flowers: Institutional Transfer and Good Governance in the Pacific Islands, Honolulu: University of Hawai'i Press.

Lendvai, N. and P. Stubbs (2007), 'Policies as translation: Situating transnational social policies', in S. Hodgson and Z. Irving (eds), Policy Reconsidered: Meanings, Politics and Practices, Bristol: Policy Press, pp. 173-90.

Lendvai, N. and P. Stubbs (2009), 'Assemblages, translation, and intermediaries in South East Europe: Rethinking transnationalism and social policy', European Societies, 11 (5), 673-95.

Levitsky, S. and L.A. Way (2006), 'Linkage versus leverage: Rethinking the international dimension of regime change', Comparative Politics, 38 (4), 379-400.

Macken-Walsh, A. (2009), 'Community action in post-socialist Lithuania', Journal of Community Development, 4 (4), 515-24.

Marsh, D. and M. Evans (2012), 'Conclusion: Special issue on policy transfer', Policy Studies, 33 (6), 587-91.

Matyas, J. and V. Zentai (eds) (2012), Capitalism from Outside? Economic Cultures in Eastern Europe after 1989, Budapest: Central European University Press.

McCann, E. and K. Ward (2012), 'Policy assemblages, mobilities and mutations: Toward a multidisciplinary conversation', Political Studies Review, 10 (3), 325-32.

McConnell, A. (2010), 'Policy success, policy failure and grey areas in-between', Journal of Public Policy, 30 (3), 345-62.

Meseguer, C. (2005), 'Policy learning, policy diffusion and the making of a new order', Annals of the American Academy of Political and Social Science, 598, 67-82.

Meyer-Sahling, J.-H. (2006), 'The institutionalization of political discretion in postcommunist civil service systems: The case of Hungary', Public Administration, 84 (3), 693-715.

Meyer-Sahling, J.-H. (2011), 'The durability of EU civil service policy in Central and Eastern Europe after accession', Governance: An International Journal of Policy, Administration, and Institutions, 24 (2), 231-60.

Mosse, D. (2005), Cultivating Development: An Ethnography of Aid Policy and Practice, London: Pluto Press.

Moynihan, D. (2006), 'Ambiguity in policy lessons: The agencification experience', Public Administration, 84, 1029-50.

Newburn, T. (2010), 'Diffusion, differentiation and resistance in comparative penality', Criminology and Criminal Justice, 10 (4), 341-53.

Neyer, J. and D. Wolf (2005), 'The analysis of compliance with international rules: 
Definitions, variables and methodology', in M. Zürn and C. Joerges (eds), Law and Governance in Postnational Europe: Compliance beyond the Nation-State, Cambridge: Cambridge University Press, pp. 40-65.

Pal, L.A. (2012), Frontiers of Governance: The OECD and Global Public Management Reform, Basingstoke: Palgrave Macmillan.

Peck, J. (2011), 'Geographies of policy: From transfer-diffusion to mobilitymutation', Progress in Human Geography, 35 (6), 773-97.

Peters, B.G. (2015), 'State failure, governance failure and policy failure: Exploring the linkages', Public Policy and Administration, 30 (3-4), 261-76.

Prince, R. (2009), 'Policy transfer as policy assemblage: Making policy for the creative industries in New Zealand', Environment and Planning A, 42, 169-86.

Rose, R. (1993), Lesson-Drawing in Public Policy: A Guide to Learning across Time and Space, Chatham, NJ: Chatham House.

Sabel, C.F. and J. Zeitlin (2012), 'Experimentalism in the EU: Common ground and persistent differences', Regulation and Governance, 6 (3), 410-26.

Schimmelfennig, F. and U. Sedelmeier (2005), 'Introduction: Conceptualising the Europeanization of Central and Eastern Europe', in F. Schimmelfennig and U. Sedelmeier (eds), The Europeanization of Central and Eastern Europe, Ithaca, NY: Cornell University Press, pp. 1-29.

Schimmelfennig, F., S. Engert and H. Knobel (2005), 'The impact of EU political conditionality', in F. Schimmelfennig and U. Sedelmeier (eds), The Europeanization of Central and Eastern Europe, Ithaca, NY: Cornell University Press, pp. 29-51.

Schneider, A. and H. Ingram (1988), 'Systematically pinching ideas: A comparative approach to policy design', Journal of Public Policy, 8 (1), 61-80.

Schwellnus, G. (2005), 'The adoption of nondiscrimination and minority protection rules in Romania, Hungary and Poland', in F. Schimmelfennig and U. Sedelmeier (eds), The Europeanization of Central and Eastern Europe, Ithaca, NY: Cornell University Press, pp. 51-71.

Sedelmeier, U. (2008), 'After conditionality: Post-accession compliance with EU law in East Central Europe', Journal of European Public Policy, 15 (6), 806-25.

Sedelmeier, U. (2011), 'Europeanisation in new member and candidate states', Living Reviews in European Governance, 6, http://www.livingreviews.org/lreg-2011-1.

Sharman, J.C. (2010), 'Dysfunctional policy transfer in national tax blacklists', Governance: An International Journal of Policy, Administration, and Institutions, 23 (4), 623-39.

Sissenich, B. (2008), 'Cross-national policy networks and the state: EU social policy transfer to Hungary and Poland', European Journal of International Relations, 14 (3), 455-87.

Stone, D. (2007), 'Market principles, philanthropic ideals, and public service values in international public policy', Political Science and Politics, 40 (3), 545-51.

Stone, D. (2012), 'Transfer and translation of policy', Policy Studies, 33 (6), 1-17.

Szent-Iványi, B. and A. Tétényi (2008), 'Transition and foreign aid policies in the Visegrad countries: A path dependent approach', Transition Studies Review, 15, 573-87.

Tews, K. (2009), 'From law-taking to policy-making: The environmental dimension of the EU accession process - challenges, risks and chances for the SEE countries', Environmental Policy and Governance, 19, 130-39.

Vachudova, M.A. (2005), Europe Undivided: Democracy, Leverage and Integration after Communism, Oxford: Oxford University Press. 